Who are the "Deficit Hawks?":

An Analysis of the Concord Coalition Congressional Vote Scores

\title{
Patrick Fisher
}

Which members of Congress are most likely to consistently support policies leading to balanced budgets? Who are the true "deficit hawks" in Congress? This paper analyzes the degree to which the nation's representatives and senators support policies conducive toward balancing the budget and reducing the national debt, as measured by the annual Fiscal Responsibility scores from 1995-2000 given to members of the House and Senate by the Concord Coalition. An analysis of the Concord Coalition vote scores indicates that a legislator's party tends to have an important effect on congressional votes on balanced budget priorities, though the direction of partisan influences is not consistent. Fiscal responsibility is related to party preference, but varies over time. That is, for some years being a Republican has a positive effect on scores by the Concord Coalition, in other years there is a positive relationship being a Democrat. The fact that the votes that the Concord Coalition find most relevant to deficit reduction cannot be placed consistently on the left or right of the American ideological spectrum differentiates it from most other interest groups from an ideological perspective.

Almost all members of Congress claim to be against budget deficits and favor balancing the federal budget, at least in the abstract. When it comes to supporting the actual policies that would lead to expenditures and revenues being in balance, however, federal legislators often abandon balanced budget principles. Who, then, are the true "deficit hawks" in Congress? That is, which members of Congress are most likely to consistently support policies leading to balanced budgets? What characteristics differentiate those legislators who are more likely to support long-term debt reduction? This paper will analyze the degree to which the nation's representatives and senators support policies conducive toward balancing the budget and reducing the national debt. In order to measure the degree to which legislators support the difficult political compromises that must be made in order to regularly produce balanced budgets I will analyze the annual "Fiscal Responsibility" scores given to members of both the House and the Senate by the Concord Coalition, an organization dedicated to balancing the federal budget.

A popular explanation for the inability of Congress to consistently produce balanced budgets is that members of Congress are unwilling to make tough choices, thus undermining the budget process. If Congress was willing to cut spending or raise taxes, the deficit problem would abate and the process would stabilize (Schick 1990). Politically, however, supporting legislation that reduces spending or raises taxes is perceived to be dangerous.

PATRICK FISHER is Assistant Professor of Political Science at Seton Hall University.

The American Review of Politics, Vol. 24, Winter, 2003: 343-360

(C)2003 The American Review of Politics 
Making life difficult for legislators is the fact that the American public tends to have contradictory opinions on the necessity of a balanced budget. They tend to deplore government spending in the abstract, but to welcome it for the specific programs that benefit them. The problem members of Congress face is that voters would like more benefits for the same or lower taxes (Peters 1991; Steinmo 1993). Thus, the nature of congressional representation may not be conducive to producing a budget process. The difficulties members of Congress face in budgeting are a direct result of the nature of a representative democracy; budget deficits are simply the result of the nation's representatives following the dictates of their constituent's desires (Fisher 1999a).

Democracy complicates budgeting because it is widely held that spending money helps one electorally and imposing costs by raising taxes is politically harmful. Members of Congress can avoid making politically difficult decisions while they blame the president, the bureaucracy, or interest groups for being the real culprit for unbalanced federal budgets. For citizens, it is difficult to assess who is responsible for deficit spending. Accountability becomes a problem - who is to blame for large budget deficits? The Concord Coalition was founded with exactly this concern in mind. Budgetary accountability is the guiding principle behind the Concord Coalition's ratings of members of Congress.

\section{The Concord Coalition's Fiscal Responsibility Scorecard}

The Concord Coalition is an anti-deficit group whose official mission is "to challenge national office holders to make the tough political choices required to balance the federal budget and keep it in balance" (Concord Coalition 2001). It was formed as a reaction against the massive budget deficits that were annually plaguing the national government throughout the 1980s and early 1990s. The Concord Coalition was founded in 1992-a year in which the deficit reached a record peacetime high of $\$ 290$ billion - by the late Senator Paul Tsongas (D-MA), former Senator Warren Rudman (R-NH), and former Secretary of the Commerce Pete Peterson. Former Senator Sam Nunn (D-GA) joined Senator Rudman as the co-chairman of the Coalition in 1997 and was replaced by former Senator Robert Kerrey (D-NB) in 2001.

The Concord Coalition purports that it is standing up for the general interest by advocating fiscal responsibility and reform of entitlement programs to ensure their viability and fairness for future generations. Legislators often get a contradictory message from voters: cut taxes, do not reduce benefits or programs, but at the same time balance the budget. The Coalition was founded on the premise that when faced with this dilemma, too few 
legislators summon the courage to make the difficult decisions necessary to balance the budget. As a result, the Coalition's goal is to try to get politicians to change direction through lobbying legislators and educating constituents.

The Concord Coalition was created at a time the federal government was producing the largest peacetime deficits in its history. After the inception of the Concord Coalition, however, the condition of the federal budget improved dramatically. Annual deficits shrunk or surpluses increased every year from 1993 to 2000 and in a development that would have previously been thought impossible, the federal government produced budget surpluses from 1998-2001, the first time since 1969 that the federal government did not run in the red. This temporarily changed the dynamics of political debate over budget priorities. To illustrate how much the budgetary picture changed: in 1993 the Congressional Budget Office projected a fiscal 1998 deficit of $\$ 357$ billion; the actual 1998 fiscal budget had a surplus of $\$ 63$ billion (Schick 2000). The euphoria over the record $\$ 232$ billion surplus in 2000, however, was short lived; within two years the nation was once again running a large deficit. Americans who temporarily witnessed a Congress debating how to spend projected budget surpluses are once again seeing the accustomed spectacle of policymakers engaging in political discourse over how to reduce projected deficits.

As a result of the budget surpluses, the Concord Coalition's mission may have seemed quixotic as federal policymakers began debating what to do with surpluses. Consequently, the Concord Coalition found itself on the defensive as the organization began lobbying members of Congress to keep surpluses as a means of reducing the national debt that has accumulated through years of deficit spending. Public opinion, however, appeared to back the organization's philosophy as polls showed that Americans were supportive of the Concord Coalition's position that the surplus should be used to reduce the national debt (Gallup 1999).

In 2000, the Congressional Budget Office and the Office of Management and Budget were predicting large surpluses for the coming decade. The Concord Coalition's skepticism of such rosy budget projections has been validated, however, by the return of deficits in 2002. To the Concord Coalition (2002), "tax advocates, defense hawks, farmers, educators, health care providers and beneficiaries, transportation planners, and veteran groups all insist that deficits are no reason to scale back their claims on a surplus that no longer exists." The Concord Coalition remains unwavering in its belief that though deficits may be good short-term politics, they are bad long-term fiscal policy. Washington policymakers, the Concord Coalition (2002) argues, "should focus on regaining budget surpluses as soon as is practicable." 
In order to influence the political process, interest groups such as the Concord Coalition publish ratings of members of Congress. To create its ratings, interest groups select particular votes - typically ranging from 10 to 40 in each house of Congress - that the group feels is relevant to their cause. If a member of Congress supports the group's positions on all the selected votes, the member receives a "perfect" score of 100. Conversely, members who oppose all the selected roll calls receive a score of 0 (Poole and Rosenthal 1997). Generally a legislator's rating equals the percentage of the selected votes on which the member of Congress favored the group's position, though some groups, including the Concord Coalition, weight votes in their ratings.

The Concord Coalition has released annual deficit reduction scores for members of Congress since 1995. The Coalition's so-called "Fiscal Responsibility Scorecard" gives each legislator a score between 0 and 100 . Votes deemed to have a significant impact on deficit reduction were assigned various weights according to their relative importance. Concord calculated the raw scores by adding the weights of a legislator's "fiscally responsible" votes and dividing this figure by the total weighted value of the votes cast by that legislator. Roll calls on which the legislator did not vote are excluded. The votes selected for the Concord Coalition's rating were chosen because they:

1) Reduced the deficit/protected the surplus

2) Supported actions that address long-term generational pressures on the federal budget

3) Kept the budget enforcement procedures strong

4) Opposed enactment of new permanent claims on the federal budget that would be difficult to finance in the future

5) Reduced or eliminated unnecessary or wasteful programs

Many critics of the congressional budget process, such as Aaron Wildavsky and Naomi Caiden (1997), Allen Schick (1990), and Dennis Ippolito $(1981,1984)$, have placed the blame for large budget deficits that the federal government produced from 1969 to 1997 on the inability of Congress to curtail spending. But one can just as easily argue that it is the inability of Congress to tax enough that makes it difficult for the federal government to balance the budget.

The fact that the Concord Coalition considers the tax side of the budget to be equal to the spending side of the budget in its political and economic importance is a beneficial attribute of the Concord Coalition's scores-the Concord Coalition measures a legislator's tendency to support deficit reduction in terms of both taxing and spending. To the Concord Coalition, "fiscal 
responsibility" is voting in favor of reduced spending or increased taxes and voting against increased spending or reduced taxes. Thus, the Concord Coalition's congressional vote scores can be seen as a means of measuring individual representatives and senators willingness to support the principles of balancing the budget from both the revenue side of the budget as well as the expenditure side of the budget.

Before moving on to an analysis of the Concord Coalition's ratings, it should be noted that by no means should the rating be viewed as an irreproachable indicator of a representative's intentions. The imperfection of interest group ratings is partly due to the fact that they are based on a relatively small number of roll calls (Kiewiet and McCubbins 1991). Interest group ratings are also influenced by the distribution of the roll calls selected, which makes legislators appear to be more extreme than they actually are (Snyder 1992). Though imperfect, over the long run interest group vote scores can provide a good indication of a legislator's behavior in office.

\section{Potential Influences on Concord Coalition Vote Scores}

What accounts for the differences among members of Congress for support of the measures to produce balanced budgets? What are the characteristics of legislators who are more likely to support legislation conducive toward balancing the budget, as measured by the Concord Coalition?

Keith Poole and Howard Rosenthal (1997) find that the only general distinction between interest groups is where they stand on the liberal-conservative axis. Nothing distinguishes the evaluations of interest groups, Poole and Rosenthal find, other than where the group stands on the ideological spectrum. Thus, nearly every vote becomes a straight liberal/conservative issue. At the same time, Poole and Rosenthal find remarkable stability of the voting continuum since the Civil War. Individual senators and representatives tend to be extremely consistent in their positions on the left-right voting continuum. Another study, however, found that voting behavior of legislators tends to vary through one's career in Congress. Specifically, party line voting and variability of voting decisions decline as one gains seniority in Congress (Stratmann 2000).

Partisanship has increasingly been found to influence the direction of congressional roll call votes and a likely factor in the Concord Coalition vote scores would be the representative's political party. Ideologically, the parties have polarized since the mid-1970s (Poole and Rosenthal 1997). An examination of budget-related roll call votes in the House from 1947 to 1990 found that congressional party conflict has not only political but structural and macroeconomic roots as well (Coleman 1997). 
Officially, the Concord Coalition is a nonpartisan entity, but it is possible that there may be partisan patterns as to which legislators are rated highly by the organization. Members of Congress tend to have a bias toward certain groups and certain interests and these groups and interests are determined to some degree by the party he or she represents (Fisher 1999b; Fenno 1978; Clausen 1973). Candidates, therefore, respond to different portions of their constituencies (Fiorina 1974). Partisanship, however, is not an infallible predictor. Roll calls often split one or both of the parties. These splits are at least in part due to the fact that legislators have parochial interests (Poole and Rosenthal 1997). Given the nature of a members' support, it can be to the benefit of individual members of Congress to go out of their way to protect the interests and preferences of his or her partisan electoral coalition. For Republicans in Congress, for instance, this may lead them to support tax cuts even if it is seems to contradict district opinion; for Democrats this may put pressure on them to increase spending totals beyond that which is favored by their constituency as a whole.

The parties different stances regarding balancing the budget may also to some degree be class based. While the Democrats have argued for using the surpluses of 1998-2001 for programs such as Social Security, Medicare, and education, the Republicans have proposed and enacted significant tax cuts. Tax cuts may give some monetary benefits to the less affluent but at the same time they will deprive government of resources for programs beneficial to those with lower-incomes (Stonecash 2000). Democrats may see attempts to cut taxes and move the budget toward deficits as a long-term means to reduce spending benefiting Democratic constituencies and thus may be more favorable toward balanced budget policies than the Republicans. Republicans, on the other hand, may see reducing the national debt as a means to reduce taxes in the long run, thus enticing them to support balancing the budget. Economic issues such as measures to balance the budget, therefore, may now be viewed as a defining ideological difference between the parties. Interestingly, however, though partisan elites have become more polarized on wedge issues, mass partisans have not necessarily followed suit (Lindaman and Haider-Markel 2002).

Partisanship in Congress may be reinforced by the prevalence of divided government, which existed every year the Concord Coalition published its Fiscal Responsibility Scorecard from 1995-2000. Divided government creates incentives for Congress to use divisive public policy debates on so-called "wedge issues" in order to damage the opposing party in future elections (Rose 2001). Another possible consequence of divided government is that if the president and Congress cannot reach agreement, then inflows and outflows will be out of balance. Depending on factors such as the state of the economy, either deficits or surpluses are possible under a divided 
government that cannot reach a budgetary consensus (Fiorina 1996). Separation of powers, therefore, should be viewed as an important influence on congressional roll call behavior. Besides the White House, Andrew Martin (2001) found that both the other legislative chamber and the Supreme Court significantly constrain members of Congress when voting on the floor. This has the potential of greatly affecting budgetary policy.

Another factor that could influence a member's vote on taxing and spending issues is the perception of electoral risk. For the most part, members of Congress tend to be extremely sensitive to public opinion in their districts. In fact, public opinion has been found to have a major impact on voting in congressional elections even when congressional actions seem to contradict public opinion. After the 1990 budget deal was completed that raised income taxes and cut entitlement spending, public opinion polls showed that the public was overwhelmingly against the measure. Yet the measure was still passed just prior to the November elections. Gary Jacobson $(1993,376)$ found that members of Congress were sensitive to the electoral implications of the 1990 budget deal, but the bill passed because "few members faced opponents who posed a serious electoral threat; most were in a position to absorb the anticipated political damage without risking their careers." In fact, Jacobson concludes that electoral risk was by far the best predictor of whether or not a member would vote against the 1990 budget; the budget passed because few perceived themselves to be at electoral risk for the upcoming elections. Stronger support in one's constituency made it easier to vote for an unpopular bill. In both the House and the Senate, however, voting for the deficit reduction bill significantly reduced an incumbent's share of the vote in the 1990 elections. Incumbents tried to avoid individual responsibility for the measure when it might have cost them reelection. To test the influence of electoral risk on legislator's Concord Coalition scores, the member's percentage of the vote in his or her last election was employed as a measure of electoral security. Since deficit reduction votes are often considered to be politically unpopular votes, it may be that members from perceived "safe" seats, that are worried less about reelection than those from more competitive seats, have the electoral freedom to make deficit reduction more of a priority.

Since the president undoubtedly affects congressional budgetary decisions, the president's popularity in one's district may influence the direction of a legislator's vote on taxing and spending issues. To appraise constituency support for the president, my examination of the Concord Coalition vote scores will utilize the support each member's district or state gave to President Clinton in the 1996 (for years 1997-2000) and 1992 (for years 1995-1996) presidential elections. Though Bill Clinton did not run as a "deficit hawk" in 1992, by 1996 deficit reduction was considered to be an 
important accomplishment of his first term in office and he made an issue of the deficit in the 1996 election in an attempt to undermine Bob Dole's tax cut proposal that became the centerpiece of the Republican nominee's campaign. Strong support for Clinton in 1996 may indicate that the constituency favored Clinton's approach to the budget and thus may have encouraged members to be supportive of deficit reduction. On the other hand, the strongest Clinton constituencies tended to be disproportionately from the relatively poor inner cities whose legislators may have regarded defending and increasing social spending as more important than deficit reduction.

Constituency interests undeniably play an important role in congressional decision-making. Since members of Congress would like to be reelected, constituency pressures impose meaningful constraints on voting behavior (Fiorina 1996; Kingdon 1989; Fenno 1978). Representatives who desire to win reelection can be expected to act in concurrence with the preferences of their constituents (Downs 1957). Members of Congress will thus be attentive to the people that they are elected to represent. In their study analyzing free trade votes in the Senate, for example, Bailey and Brady (1998) found strong evidence of dyadic representation on roll call voting.

Congress was created in order to provide a mechanism through which the people's preferences could be translated into public policy. Congress, however, is not a neutral institution making laws which benefit all citizens of the United States equally. The decisions arrived at by Congress have varying consequences for citizens, depending on the demographics of their constituents. Since individual House districts tend to be relatively homogeneous, but heterogeneous as a whole (that is, they vary among each other), if we expect members of Congress to be responsive to the wishes of their constituents, it follows that members of Congress will represent their constituents differently, depending upon the characteristics of their district (Froman 1963). The demographic characteristics of constituencies substantially affect the explanation of roll call votes (Page et al. 1984). Thus, citizen preferences may be expected to vary according to their demographic characteristics, which in turn influence the political behavior of their representatives in Congress.

The influence of one's constituency on legislative behavior can be seen by the fact that heterogeneity of electorates has been found to be an important factor in determining roll call votes (Bailey and Brady 1998). Due to the nature of congressional representation, members of Congress may have parochial interests when it comes to budgeting. Since the United States is such a vast and diverse nation, taxing and spending issues inevitably affect constituencies differently. To measure constituency influence on budgetary matters, the constituency's per capita income and the district's percentage of the population that is over 65 years of age were chosen as predictors. 
There are a number of reasons we might expect these predictors to shape a legislator's willingness to support legislation that the Concord Coalition deems as favorable toward balancing the budget. The higher a district's per capita income, the more reluctant a representative may be in supporting tax increases, since that representative's constituents would probably pay a disproportionate amount of the increased revenues. At the same time, the constituents of poorer districts may make it more difficult for their representative to support balanced budget policies because these districts have potentially the most to lose by cutting federal spending. In other words, the fact that the wealthy would have the most to lose with increased taxes and the poor the most to lose with decreased spending may put pressure on representatives with constituencies that have high and low per capita income levels to be hostile to particular type of balanced budget legislation. In a similar vein, the number of senior citizens in the district also may influence the behavior of its representative in regards to balancing the budget. The percentage of the population that is over 65 was chosen as an independent variable because of the Concord Coalition's advocacy of entitlement reform. According to the Concord Coalition, age-related entitlement programs such as Social Security and Medicare need to be reformed in order to prevent too much strain on the federal budget in the future. Thus, a higher proportion of seniors may encourage representatives to take actions not conducive toward balancing the budget because the elderly have potentially so much to lose in age-related entitlement programs with entitlement reform.

Finally, the political culture of one's constituency may influence the votes of legislators on balanced budget matters. Political culture consists of a shared set of ideas about the role of government and who should influence public policy. Political culture, as measured by Daniel Elazar's (1984) prototype classifications of American political subcultures, may be a determinant of whether or not a legislator supports balanced budget principles. Elazar's theory of American political culture has been found to be related to a number of social pathologies and life quality measures (Lieske 1993) and substantial support for Elazar's typology and its linkage to the formal process of state politics has been found (Herzik 1985). According to Elazar, the national political culture is the synthesis of three major political subcultures that are dominant in varying parts of the country. Elazar terms these subcultures moralistic, individualistic, and traditionalistic.

Of particular interest on budgetary matters is the moralistic political culture, which stresses the conception of the commonwealth as the basis for democratic government. Politics in the moralistic subculture is viewed as being a positive activity and good government is measured by the degree to which it promotes the public good. Communitarian principles dictate that government has the responsibility to promote the public welfare. Due to its 
stress on the public good, moralistic political cultures (which are dominant in New England, the Great Lakes region, and the west coast) may be expected to be more likely to elect legislators that support balanced budget principles.

\section{Findings}

To measure the degree by which party, electoral risk, presidential popularity, constituency per capita income, constituency elderly population and political culture influenced the voting behavior of representatives and senators on issues related to balancing the budget, ordinary least square models were utilized for both the House (Table 1) and the Senate (Table 2). The member's party, percentage of the vote in the legislator's last election, district presidential vote for Clinton, district per capita income, the percentage of the member's constituency that is over 65 , and whether or not the legislator was a representative in a state with a moralistic subculture were tested as independent variables with annual Concord Coalition vote scores from 19952000 as the dependent variable.

The results of these regressions reveal that a member's partisan affiliation tends to have a significant effect on congressional votes on balanced budget priorities. For the House, the representative's party was statistically significant $(\mathrm{p}<.05)$ for four of the six years studied and for the Senate, the senator's party was statistically significant $(p<.05)$ for five out of the six years. This is consistent with previous findings that the parties have polarized since the mid-1970s (Fisher 1999b; Poole and Rosenthal 1997). In terms of economic policy, the collapse of Keynesian notions in the stagflation of the 1970s has lead to more party conflict (Coleman 1997).

The other independent variables tested varied in their strength as predictors of congressional budgetary actions. In the House models, the percentage of the vote one received in the previous congressional election was statistically significant $(\mathrm{p}<.05)$ for two years and district support for Bill Clinton in 1996 was statistically significant $(p<.05)$ for three years. Interestingly, there was a negative relationship with district support for Clinton and a legislator's Concord Coalition votes scores for every year from 19952000. District per capita income had a positive effect on Concord Coalition vote scores for every year of the analysis and was statistically significant $(\mathrm{p}<.05)$ for three years. In order words, House members from wealthier districts tended to be more supportive of balanced budget legislation. The size of the elderly population in one's district proved to be a poor predictor as it had no substantial relationship on Concord Coalition vote scores in any year. In the Senate, tested variables other than partisanship were relatively poor predictors of a senator's Concord Coalition vote scores; other than the 
Table 1. Influences on Concord Coalition Vote Scores, House of Representatives

\begin{tabular}{|c|c|c|c|c|c|c|}
\hline \multirow[b]{2}{*}{ Variable } & \multicolumn{6}{|c|}{$\begin{array}{c}\text { Concord Coalition Vote Score } \\
\text { b (t value })\end{array}$} \\
\hline & 1995 & 1996 & 1997 & 1998 & 1999 & 2000 \\
\hline Party & $\begin{array}{l}-12.713 \\
(-9.769)^{* * *}\end{array}$ & $\begin{array}{l}5.086 \\
(3.416)^{* * *}\end{array}$ & $\begin{array}{r}.637 \\
(.388)\end{array}$ & $\begin{array}{l}14.046 \\
(7.060)^{* * *}\end{array}$ & $\begin{array}{l}13.880 \\
(6.741)^{* * *}\end{array}$ & $\begin{array}{r}1.948 \\
(1.251)\end{array}$ \\
\hline $\begin{array}{l}\% \text { Vote in } \\
\text { Last Election }\end{array}$ & $\begin{array}{r}-.064 \\
(-1.662)\end{array}$ & $\begin{array}{c}.001 \\
(.013)\end{array}$ & $\begin{array}{c}-.176 \\
(-2.863)^{* *}\end{array}$ & $\begin{array}{r}.050 \\
(.668)\end{array}$ & $\begin{array}{c}.017 \\
(.298)\end{array}$ & $\begin{array}{c}.112 \\
(2.617)^{* *}\end{array}$ \\
\hline $\begin{array}{l}\text { District } \\
\text { Clinton Vote }\end{array}$ & $\begin{array}{c}-.188 \\
(-3.617)^{* * *}\end{array}$ & $\begin{array}{r}-.059 \\
(-1.004)\end{array}$ & $\begin{array}{c}-.286 \\
(-4.181)^{* * *}\end{array}$ & $\begin{array}{l}-.013 \\
(-.154)\end{array}$ & $\begin{array}{c}-.208 \\
(-2.525)^{*}\end{array}$ & $\begin{array}{r}-.077 \\
(-1.245)\end{array}$ \\
\hline $\begin{array}{l}\text { District Per } \\
\text { Capita Income }\end{array}$ & $\begin{array}{r}.074 \\
(.618)\end{array}$ & $\begin{array}{c}.677 \\
(4.968)^{* * *}\end{array}$ & $\begin{array}{c}.703 \\
(4.617)^{* * *}\end{array}$ & $\begin{array}{c}.378 \\
(2.052)^{*}\end{array}$ & $\begin{array}{c}.163 \\
(.871)\end{array}$ & $\begin{array}{r}.138 \\
(.979)\end{array}$ \\
\hline $\begin{array}{l}\% \text { District } \\
\text { Over } 65\end{array}$ & $\begin{array}{l}-.049 \\
(-.406)\end{array}$ & $\begin{array}{l}-.081 \\
(-.591)\end{array}$ & $\begin{array}{l}-.152 \\
(-.974)\end{array}$ & $\begin{array}{l}-.175 \\
(-.933)\end{array}$ & $\begin{array}{r}-.217 \\
(-1.137)\end{array}$ & $\begin{array}{r}-.172 \\
(-1.192)\end{array}$ \\
\hline $\begin{array}{l}\text { Moralist } \\
\text { Subculture }\end{array}$ & $\begin{array}{c}2.022 \\
(1.800)\end{array}$ & $\begin{array}{l}3.471 \\
(2.695)^{* *}\end{array}$ & $\begin{array}{r}1.843 \\
(1.271)\end{array}$ & $\begin{array}{c}2.781 \\
(1.585)\end{array}$ & $\begin{array}{l}6.566 \\
(3.659)^{* * *}\end{array}$ & $\begin{array}{l}4.889 \\
(3.607)^{* * *}\end{array}$ \\
\hline Constant & $\begin{array}{l}61.707 \\
(16.009)^{* * *}\end{array}$ & $\begin{array}{l}37.730 \\
(8.618)^{* * *}\end{array}$ & $\begin{array}{l}73.147 \\
(14.047)^{* * *}\end{array}$ & $\begin{array}{l}22.468 \\
(3.570)^{* * *}\end{array}$ & $\begin{array}{l}36.220 \\
(5.978)^{* * *}\end{array}$ & $\begin{array}{l}28.003 \\
(6.139)^{* * *}\end{array}$ \\
\hline R-squared & .385 & .092 & .162 & .169 & .140 & .048 \\
\hline $\begin{array}{l}\text { Standard Error } \\
\text { of Estimate }\end{array}$ & 10.338 & 11.794 & 13.388 & 16.234 & 16.585 & 12.474 \\
\hline $\mathrm{F}$ & $43.420 * * *$ & $6.963 * * *$ & $13.666^{* * *}$ & $14.453 * * *$ & * $11.558^{* * *}$ & * $3.587 * *$ \\
\hline $\mathrm{N}$ & 431 & 427 & 428 & 430 & 431 & 428 \\
\hline$* * * \mathrm{p}<.001 ; * * \mathrm{p}$ & $* \mathrm{p}<.05$ & & & & & \\
\hline
\end{tabular}

moralist subculture variable no other independent variable was statistically significant in any of the Senate models.

In the House, whether or not a member was from a district with a moralistic subculture turned out to be a relatively strong predictor of Concord Coalition vote scores. For every year there was a positive relationship between moralistic subculture and representatives' Fiscal Responsibility scores, and this relationship was statistically significant $(p<.05)$ in three of the House regression models. The strength of the moralistic subculture as a predictor in the House can also be seen in Table 3, which compares the average annual Concord Coalition vote scores of those members of Congress 
Table 2. Influences on Concord Coalition Vote Scores, U.S. Senate

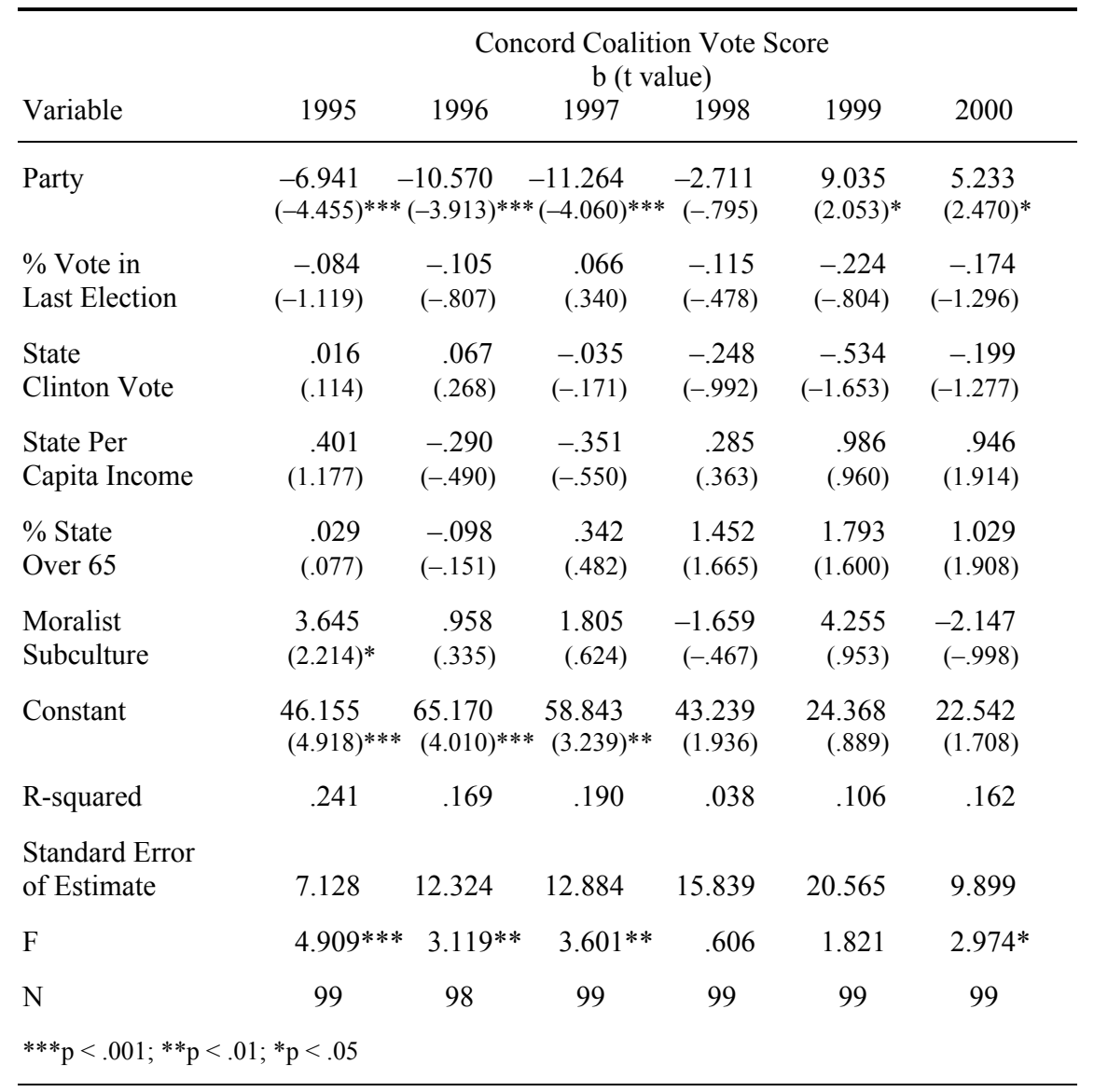

representing moralistic subcultures and those who represent other (individualistic or traditionalistic) subcultures. For every year from 1995-2000, House members from moralistic subculture districts had higher mean annual vote scores, a relationship that was statistically significant $(\mathrm{p}<.05)$ in five out of the six years.

\section{Partisanship and Concord Coalition Vote Scores}

An interesting characteristic of the effect of partisanship on the Concord Coalition vote scores is the fact that even though party is a statistically significant predictor of Concord Coalition vote scores, the direction of 
Table 3. Mean Annual Concord Coalition Vote Scores by Political Subculture

\begin{tabular}{|c|c|c|c|}
\hline Year & Moralistic & Non-Moralistic & T-Ratio \\
\hline \multicolumn{4}{|c|}{ House of Representatives } \\
\hline 1995 & 46.68 & 43.55 & $2.306^{*}$ \\
\hline 1996 & 49.88 & 46.16 & $2.916 * *$ \\
\hline 1997 & 58.79 & 55.43 & $2.212 *$ \\
\hline 1998 & 38.25 & 34.80 & 1.860 \\
\hline 1999 & 40.47 & 33.11 & $4.011 * * *$ \\
\hline 2000 & 37.54 & 32.90 & $3.506 * * *$ \\
\hline \multicolumn{4}{|c|}{ Senate } \\
\hline 1995 & 48.17 & 44.36 & $2.358^{*}$ \\
\hline 1996 & 52.91 & 51.28 & .591 \\
\hline 1997 & 57.44 & 55.22 & .772 \\
\hline 1998 & 44.97 & 45.70 & -.224 \\
\hline 1999 & 31.44 & 26.36 & 1.16 \\
\hline 2000 & 29.28 & 31.30 & -.929 \\
\hline \multicolumn{4}{|c|}{$\begin{array}{l}\text { Bold indicates political subculture with highest mean annual vote score. } \\
\text { States that are classified as having a Moralistic subculture are: California, Colorado, Idaho, Iowa } \\
\text { Kansas, Maine, Michigan, Minnesota, Montana, Nebraska, New Hampshire, North Dakota, Oregon } \\
\text { South Dakota, Utah, Vermont, Washington, and Wisconsin. } \\
* * * \mathrm{p}<.001 ;{ }^{* *} \mathrm{p}<.01 ;{ }^{*} \mathrm{p}<.05\end{array}$} \\
\hline
\end{tabular}

partisan influences in not consistent. That is, for some years being a Republican has a positive effect on scores by the Concord Coalition, in other years there is a positive relationship being a Democrat. In the House regression models, Democratic partisanship had a positive influence on Concord Coalition vote scores for five years (1996-2000), while being a Republican had a positive influence for one year (1995). In the Senate models, the Democrats had a positive influence for two years $(1999,2000)$ and the Republicans for four (1995-2000). This suggests that both Democrats and Republicans can occasionally make the claim of being the party of fiscal responsibility.

Poole and Rosenthal (1997), as stated previously, found that a liberal/ conservative ordering of members of Congress is a predominant feature of nearly all roll call voting. The Concord Coalition's congressional roll call vote ratings, however, do not fit nicely on the standard left-right political spectrum, suggesting that the political dynamics of deficit reduction are different from those of other issues. Also contrary to Poole and Rosenthal's findings is the fact that individual senators and representatives do not uniformly tend to be consistent in the annual scores they receive from the Concord Coalition. 
Table 4. Concord Coalition's Top Five Annual "Fiscal Responsibility" Score

\begin{tabular}{lll}
\hline House of Representatives & & \\
2000 & 1999 & 1998 \\
Doggett (D-TX) & Doggett (D-TX) & Sanford (R-SC) \\
Sanford (R-SC) & Luther (D-MN) & Skaggs (D-CO) \\
Coburn (R-OK) & Meehan (D-MA) & Barrett (D-WI) \\
Royce (R-CA) & Barrett (D-WI) & Kind (D-WI) \\
Stenholm (D-TX) & Minge (D-MN) & Castle (R-DE) \\
1997 & 1996 & 1995 \\
Meehan (D-MA) & Morella (R-MD) & Klug (R-WI) \\
Barrett (D-WI) & Porter (R-IL) & Duncan (R-TN) \\
Campbell (R-CA) & Roukema (R-NJ) & Upton (R-MI) \\
Minge (D-MN) & Campbell (R-CA) & Blute (R-MA) \\
Davis (R-FL) & Meehan (D-MA) & Morella (R-MD) \\
Senate & & \\
2000 & 1999 & 1998 \\
Feingold (D-WI) & Feingold (D-WI) & Coats (R-IN) \\
Voinovich (R-OH) & Voinovich (R-OH) & Feingold (D-WI) \\
McCain (R-AZ) & Graham (D-FL) & Moynihan (D-NY) \\
Kerrey (D-NB) & McCain (R-AZ) & Robb (D-VA) \\
Bryan (D-NV) & Fitzgerald (R-IL) & Grams (R-MN) \\
1997 & 1996 & 1995 \\
Robb (D-VA) & Kohl (D-WI) & Brown (R-CO) \\
Kohl (D-WI) & Brown (R-CO) & Kerrey (D-NB) \\
Grassley (R-IA) & Cohen (R-ME) & Nunn (D-GA) \\
McCain (R-AZ) & Jeffords (R-VT) & Robb (D-VA) \\
Nickles (R-OK) & Nunn (D-GA) & Snowe (R-ME) \\
\hline
\end{tabular}

The fact that the Concord Coalition may be an atypical interest group that cannot be distinguished by where the group stands on the ideological spectrum can also be seen by looking at the individual members of the House and Senate who received the highest annual "Fiscal Responsibility" scores. As can be seen from Table 4, the highest scores given to House members include legislators from across the political spectrum. In 2000, for example, the top five Concord Coalition scores in the House included a representative who would probably be regarded by most congressional observers as a relatively liberal Democrat (Lloyd Doggett-TX), a conservative Democrat (Charles Stenholm-TX), and three conservative Republicans (Mark Sanford-SC, Tom Coburn-OK, and Ed Royce-CA). While in 1995 Republican representatives had the five highest scores, in 1999 Democratic representatives had the five highest scores. 
That neither party dominates the Concord Coalition's list of high scores can also be seen in the organization's Senate ratings. In every year that the Concord Coalition published its ratings from 1995-2000 neither party had more than three of the highest five scores. The senators who received the highest annual rating by the Concord Coalition comprise a truly heterogeneous group from across the political spectrum; those who received the highest annual score include Democrats Russ Feingold-WI, Charles Robb-VA, and Herb Kohl-WI, and Republicans Daniel Coats-IN and Hank BrownCO.

To further analyze the importance of partisanship, the differences for the mean Democratic and Republican Concord Coalition vote scores were compared for the House and the Senate (Table 5). A distinguishable pattern can be seen. In the House, in 1995 and 1997 the Republicans had higher mean Concord Coalition vote scores and in 1996 and from 1998-2000 the Democrats did. In the Senate, the Republicans had higher scores from 19951998 and the Democrats in 1999 and 2000. Thus, since the Concord Coalition began giving scores to members of Congress in 1995 there has been a shift from the Republicans getting overall higher scores to the Democrats being more supportive of the organization's goals. The dramatic change in the party's Concord Coalition vote scores can be especially seen in the

Table 5. Mean Annual Concord Coalition Vote Scores by Party

\begin{tabular}{|c|c|c|c|c|}
\hline Year & $\begin{array}{c}\text { Deficit }(-) \text { or } \\
\text { Surplus }(+)\end{array}$ & Democrats & Republicans & T-Ratio \\
\hline \multicolumn{5}{|c|}{ House of Representatives } \\
\hline 1995 & -164.0 & 36.00 & 51.51 & $-15.281 * * *$ \\
\hline 1996 & -107.5 & 49.03 & 45.82 & $2.718 * *$ \\
\hline 1997 & -22.0 & 53.92 & 58.78 & $-3.511 * * *$ \\
\hline 1998 & +69.2 & 43.05 & 29.20 & $8.824 * * *$ \\
\hline 1999 & +125.5 & 40.74 & 30.10 & $6.534 * * *$ \\
\hline 2000 & +236.4 & 34.77 & 33.82 & .766 \\
\hline \multicolumn{5}{|c|}{ Senate } \\
\hline 1995 & -164.0 & 42.34 & 48.74 & $-4.381 * * *$ \\
\hline 1996 & -107.5 & 46.38 & 56.81 & $-4.291 * * *$ \\
\hline 1997 & -22.0 & 49.69 & 61.20 & $-4.542 * * *$ \\
\hline 1998 & +69.2 & 43.98 & 46.64 & -.847 \\
\hline 1999 & +125.5 & 33.04 & 24.06 & $2.184 * *$ \\
\hline 2000 & +236.4 & 33.98 & 27.64 & $3.149 * *$ \\
\hline \multicolumn{5}{|c|}{$\begin{array}{l}\text { Bold indicates party with highest mean annual vote score. } \\
\text { Deficit and surplus figures in billions of dollars. } \\
* * * \mathrm{p}<.001 ; * * \mathrm{p}<.01 ; * \mathrm{p}<.05\end{array}$} \\
\hline
\end{tabular}


House. In 1995, the Republicans had an average score of over 51 and the Democrats of 36. By 1998, however, the Republicans' mean score had declined to 29 and the Democrats' had increased to 43. Unquestionably an important shift occurred.

Why have the Democrats replaced the Republicans as being more likely to support the Concord Coalition's aspirations? One possible explanation has to do with the arrival of the federal budget surplus and the parties' budgetary priorities. As Table 5 shows, from 1995-1997 with the federal government still running deficits, Republicans tended to score higher with the Concord Coalition and after the arrival of surpluses in 1998 the Democrats began receiving higher scores. When Republicans took control of Congress after the 1994 elections, annual deficits were still relatively high. Thus, the Republicans, even though they publicly supported significant tax cuts, made cutting domestic spending a higher legislative priority. With a Democrat in the White House, congressional Republicans may have decided they would be more successful passing legislation that reduced spending than enacting tax cuts. The budget agenda changed, however, with the arrival of surpluses beginning in 1998. With the advent of federal budget surpluses the Republicans made a more concentrated effort to reduce taxes and the Democrats, playing defensive, voted against the tax cuts arguing that the surplus would be better used for domestic programs and reducing the national debt. Thus, immediately after the Republicans took control of Congress they had higher Concord Coalition vote scores because they controlled the legislative agenda and supported a number of measures to reduce federal spending that Democrats opposed. With the federal government running in the black for the first time in thirty years beginning in 1998, however, the Republicans saw an opportunity to make tax cuts a greater priority, lowering their scores, while Democrats' opposition of tax cuts garnered them higher Fiscal Responsibility scores.

To a large degree, therefore, which party is seen to be a better advocate of balanced budget policies has to do with whether it is a spending or taxing issue that is being debated. The Republicans are going to be seen as the better advocates of the balanced budget when it comes to attempts to keep spending down, but the Democrats are going to be seen as better defenders of balanced budget priorities when it comes to tax legislation. Thus, both parties can occasionally make the claim that they are the party of fiscal responsibility, depending on what type of issue - taxing or spending - is dominating the budget agenda. Given the major priority tax reduction has been given in the George W. Bush administration, including the significant tax cuts in the 2001 Budget Reconciliation Bill - a measure the Concord Coalition strongly opposed because it eliminated the projected federal surpluses over the next decade - it may be safe to predict that the Democrats 
can be expected to receive higher vote scores by the Concord Coalition in the foreseeable future.

\section{Conclusion}

As my findings indicate, there is no easy answer to the question "who are the deficit hawks?"- at least when measured by the congressional vote scores of the Concord Coalition. An analysis of the Concord Coalition Fiscal Responsibility vote scores indicates that a legislator's party tends to have an important effect on congressional votes on balanced budget priorities, though the direction of partisan influences is not consistent. That is, though party preference tends to be an important determinant in annual votes on deficit reduction, the party that is most likely to be supporting deficit reduction varies from year-to-year. In this regard, the Concord Coalition's congressional vote scores put it in an unique situation when it comes to interest group ideology. The fact that the votes that the Concord Coalition find most relevant to deficit reduction cannot be placed consistently on the left or right of the American ideological spectrum distinguishes it from most other interest groups and contradicts Poole and Rosenthal's (1997) finding that the only general distinction between interest groups is where they stand on the ideological spectrum. To a significant degree, the party that is seen by the Concord Coalition to be a better advocate of balanced budget policies is determined by whether it is a spending or taxing issue that is being debated.

\section{REFERENCES}

Arnold, R. Douglas. 1990. The Logic of Congressional Action. New Haven, CT: Yale University Press.

Bailey, Michael, and David W. Brady. 1998. Heterogeneity and Representation: The Senate and Free Trade. American Journal of Political Science 42:524-544.

Clausen, Aage. 1973. How Congressmen Decide: A Policy Focus. New York: St. Martin's Press.

Coleman, John. 1997. The Decline and Resurgence of Congressional Party Conflict. The Journal of Politics 59:165-184.

Concord Coalition. 2001. Introduction to the Concord Coalition's Fiscal Responsibility Scorecard. http://www.concordcoalition.org. July 2.

Concord Coalition. 2002. Deficits are Back, and the Budget Bazaar is Open for Business. The Concord Coalition's Report on Fiscal Responsibility 4:1-4.

Downs, Anthony. 1957. An Economic Theory to Democracy. New York: Harper.

Downs, Anthony. 1960. Why Government is Too Small in a Democracy. World Politics 12:541-563.

Elazar, Daniel. 1984. American Federalism: A View from the States, 3rd ed. New York: Harper and Row.

Fenno, Richard F. 1978. Home Style. Boston: Little, Brown, and Company. 
Fiorina, Morris. 1974. Representatives, Roll Calls, and Constituencies. Lexington, MA: Lexington Books.

Fiorina, Morris. 1996. Divided Government, 2nd ed. Boston: Allyn and Bacon.

Fisher, Patrick. 1999a. Political Explanations for the Difficulties in Congressional Budgeting. The Social Science Journal 36:149-161.

Fisher, Patrick. 1999b. The Prominence of Partisanship in the Congressional Budget Process. Party Politics 5:225-236.

Froman, Louis A. 1963. Congressmen and Their Constituencies. Chicago: Rand McNally.

Gallup Organization. 1999. Gallup Poll Topics: Taxation. www.gallup.com/poll/ indicators/indtaces.asp August 17-18.

Herzik, Eric B. 1985. The Legal-Formal Structuring of State Politics: A Cultural Explanation. Western Political Quarterly 38:413-423.

Ippolito, Dennis S. 1981. Congressional Spending. Ithaca, NY: Cornel University Press.

Ippolito, Dennis S. 1984. Hidden Spending. Chapel Hill: University of North Carolina Press.

Jacobs, Lawrence R., Eric D. Lawrence, Robert Y. Shapiro, and Steven S. Smith. 1998. Congressional Leadership on Public Opinion. Political Science Quarterly 113:21-41.

Jacobson, Gary C. 1993. Deficit-Cutting Politics and Congressional Elections. Political Science Quarterly 108:375-402.

Kiewiet, D. Roderick and Mathew McCubbins. 1991. The Logic of Delegation: Congressional Parties and the Logic of Delegation. Chicago: University of Chicago Press.

Kingdon, John W. 1989. Congressmen's Voting Decisions, 3rd ed. Ann Arbor: University of Michigan Press.

Lieske, Joel. 1993. Regional Subcultures of the United States. Journal of Politics 55:888913.

Lindaman, Kara, and Donald P. Haider-Markel. 2002. Issue Evolution, Political Parties, and the Culture Wars. Political Research Quarterly 55:91-110.

Martin, Andrew D. 2001. Congressional Decision Making and the Separation of Powers. American Political Science Review 95:361-378.

Page, Benjamin I., Robert Y. Shapiro, Paul W. Gronke, and Robert W. Rosenberg. 1984. Constituency, Party, and Representation in Congress. Public Opinion Quarterly 48:741-756.

Peters, B. Guy. 1991. The Politics of Taxation. Cambridge, MA: Blackwell.

Poole, Keith T. and Howard Rosenthal. 1997. Congress: A Political-Economic History of Roll Call Voting. New York: Oxford University Press.

Rose, Melody. 2001. Divided Government and the Rise of Social Regulation. Policy Studies Journal 29:611-626.

Rose, Richard. 1986. Maximizing Tax Revenue While Minimizing Political Costs. Journal of Public Policy 5:289-320.

Schick, Allen. 1990. The Capacity to Budget. Washington, DC: The Urban Institute.

Schick, Allen. 2000. A Surplus, If We Can Keep It. The Brookings Review 18:36-39.

Snyder, James M., Jr. 1992. Artificial Extremism in Interest Group Ratings. Legislative Studies Quarterly 17:319-345.

Steinmo, Sven. 1993. Taxation and Democracy. New Haven, CT: Yale University Press.

Stonecash, Jeffrey M. 2000. Class and Party in American Politics. Boulder, CO: Westview Press.

Stratmann, Thomas. 2000. Congressional Voting and Legislative Careers: Shifting Positions and Changing Constraints. American Political Science Review 94:665-676.

Wildavsky, Aaron, and Namoi Caiden. 1997. The New Politics of the Budgetary Process, 3rd ed. New York: Longman. 